\title{
Towards an Optical Biopsy during Visceral Surgical Interventions
}

\author{
David Benjamin Ellebrecht ${ }^{\mathrm{a}, \mathrm{c}}$ Sarah Latus ${ }^{\mathrm{b}}$ Alexander Schlaefer ${ }^{\mathrm{b}}$ \\ Tobias Keck ${ }^{c}$ Nils Gessert ${ }^{b}$

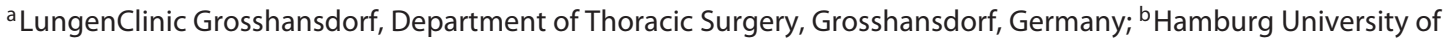 \\ Technology, Institute of Medical Technology, Hamburg, Germany; ' University Medical Center Schleswig-Holstein, \\ Campus Lübeck, Department of Surgery, Lübeck, Germany
}

\section{Keywords}

Surgery · Confocal laser microscopy · Optical coherence tomography · Laparoscopy · Laparotomy · Deep learning

\begin{abstract}
Background: Cancer will replace cardiovascular diseases as the most frequent cause of death. Therefore, the goals of cancer treatment are prevention strategies and early detection by cancer screening and ideal stage therapy. From an oncological point of view, complete tumor resection is a significant prognostic factor. Optical coherence tomography (OCT) and confocal laser microscopy (CLM) are two techniques that have the potential to complement intraoperative frozen section analysis as in vivo and real-time optical biopsies. Summary: In this review we present both procedures and review the progress of evaluation for intraoperative application in visceral surgery. For visceral surgery, there are promising studies evaluating OCT and CLM; however, application during routine visceral surgical interventions is still lacking. Key Message: OCT and CLM are not competing but complementary approaches of tissue analysis to intraoperative frozen section analysis. Although intraoperative application of OCT and CLM is at an early stage, they are two promising techniques of intraoperative in vivo and real-time tissue examination. Additionally, deep learning strategies provide a significant supplement for automated tissue detection.

(c) 2020 S. Karger AG, Basel
\end{abstract}

\section{Introduction}

Cancer is the second leading cause of death globally [1] and will be the leading cause of death in a few decades due to the ageing world population and better treatment of cardiovascular disease [2]. In 2018, 18.1 million new cancer cases and 9.6 million cancer deaths occurred [2]. Lung cancer is already the sixth most frequent cause of death worldwide [3]. In comparison, lung cancer ranked ninth in the WHO Global Cause of Death Report some years ago [3]. In high-income countries there are even 3 malignancies among the top 10 most frequent causes of death $[2,3]$. Even in low-income countries, the cumulative risk of cancer is already 1:8 for men and 1:10 for women [4]. The GLOBOCAN study showed that cancer ranks as the first or second cause of premature death in almost 100 countries worldwide [2]. The economic impact of cancer is considerable. The total annual cost of cancer was estimated at approximately USD 1.16 trillion in 2010, and treatment costs are expected to rise further $[4,5]$.

In women, breast cancer is the most frequently diagnosed malignancy $(24.2 \%)$, followed by colorectal cancer (9.5\%), and lung cancer (8.4\%). Also, the highest mortality is found in women for these three entities (breast cancer, 15\%; lung cancer, $13.8 \%$; colorectal cancer, 9.5\%).

David Benjamin Ellebrecht and Sarah Latus contributed equally to this work. 
Fig. 1. Penetration depth and resolution of

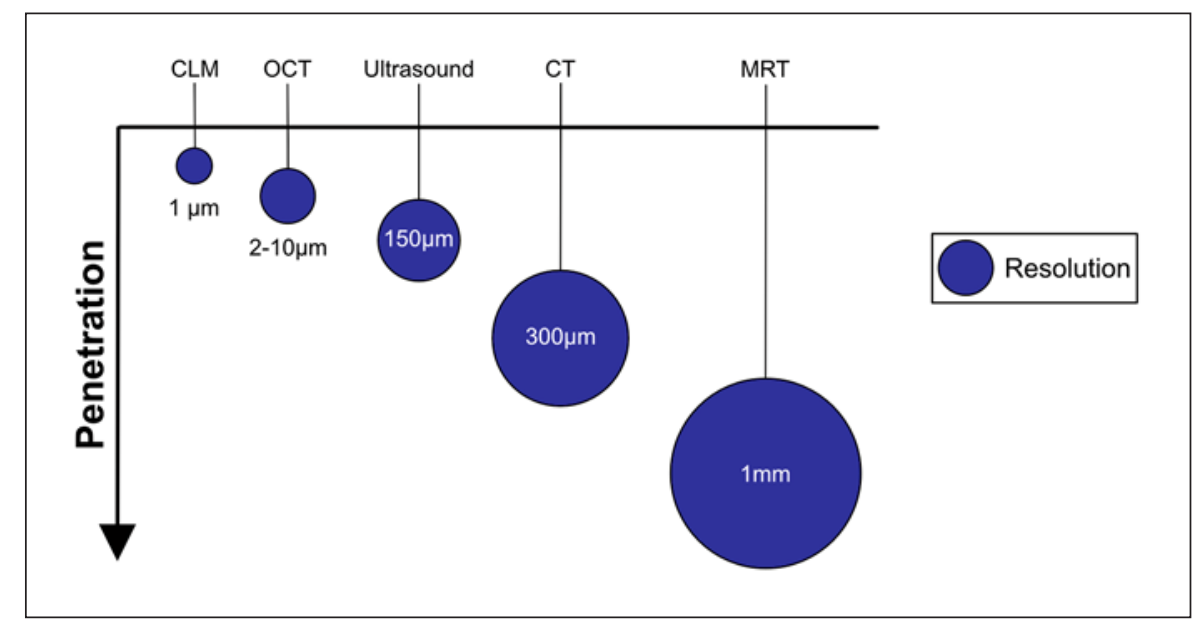
tissue examination devices.

Lung cancer is the most common malignant cancer diagnosis in men (14.5\%), followed by prostate cancer (13.5\%) and colorectal cancer (10.9\%). Lung cancer also has the highest mortality rate (22\%), followed by hepatocellular carcinoma (10.2\%) and gastric carcinoma $(9.5 \%)[2,4,5]$.

Despite existing efforts to reduce the risk of cancer and early cancer detection, diagnoses are often only made in advanced malignant stages. Consequently, in addition to prevention strategies, the goal of cancer treatment is early detection by cancer screening and ideal stage therapy. In this context, the gold standard of treatment of most solid tumors is complete surgical excision. Complete tumor removal determines a curative surgical intervention [6]. In this context, tumor-free resection margins are among the most prognostic factors [6-8].

Frozen sections play a potential role in intraoperative characterization of resection margins and are the key component of a surgeon's decision. However, operation procedures are often stalled for 20-60 min while histological results are awaited [9], which is costly [6]. In addition, only a limited number of sampling points are possible and repetitive examination can be difficult.

There is an increasing request for intraoperative navigation tools enabling individual cancer resection while protecting healthy tissue $[6,10]$. The effort of introducing minimally invasive surgical techniques in oncological surgery entailed by reduced tactility and, in some cases, a limited intraoperative overview.

In addition to macroscopic optical navigation techniques such as fluorescence angiography using indocyanine green [11-13], various methods of tissue identification are being tested. In this context, optical coherence tomography (OCT) and confocal laser microscopy (CLM) are two tools for intraoperative tissue navigation. Both techniques enable tissue examination with microscopic resolution (Fig. 1). While potentially providing more intraoperative information, enormous difficulties arise in dealing with the surgical procedure and tissue identification. The solution could be the intraoperative support of the surgeon by computer-assisted image analysis using deep learning strategies [14]. In this review, we will explain OCT and CLM for intraoperative navigation and will give an overview of the current opportunities of optical biopsy during visceral surgical procedures, including approaches for automated tissue analysis.

\section{Optical Coherence Tomography}

\section{Principle of OCT}

OCT is an interferometric imaging modality that uses near infrared light for the acquisition of high-resolution $1 \mathrm{D}$ depth profiles (A-scans) of tissues. A laser beam is directed towards a tissue and the reflected light interferes with that of the reference arm of the OCT system (Fig. 2). Different reflective properties of subsurface tissue structures and boundaries lead to varying gray value intensities along the A-scan. Hence, morphological information and optical characteristics of tissues are observable. In general, OCT cross-sectional images or volumes are observed by deflecting the laser along one or two axes [15]. In addition to the gray values, the A-scan phase information can be used, for example, for Doppler OCT [16], needle-based elastography $[17,18]$, or OCT angiography [19] studies.

Two Fourier domain OCT systems have been proposed, namely swept-source OCT (SS-OCT) and spectral domain OCT (SD-OCT) [20]. Broadband light sources are used in SD-OCT systems. In contrast, SS-OCT systems are equipped with narrow-band swept laser sources [21]. The latter systems allow for A-scan rates of above 1 MHz. Depending on the light source, OCT provides an axial resolution of $2-10 \mathrm{~mm}$ and an imaging depth of about $1 \mathrm{~mm}$ in tissues. 
Fig. 2. OCT system architecture. A light source emits infrared light which is split at a fiber optical coupler. Light reflected from a reference and a sample arm form an interference spectrum that is measured at a detector. A single scan results in a $1 \mathrm{D}$ depth profile (A-Scan). By taking multiple measurements at neighboring locations, several A-Scans can be combined to a $2 \mathrm{D}$ image (B-Scan) after signal processing (SP). Two optical setups for scanning small locations are sketched and their related cross-sectional B-scans are shown. A Optical scanning setup where mirrors redirect the light beam to form 2D and 3D scans. B Rotation and translation of a side-viewing needle probe which results in a cylinder-like $3 \mathrm{D}$ image volume.

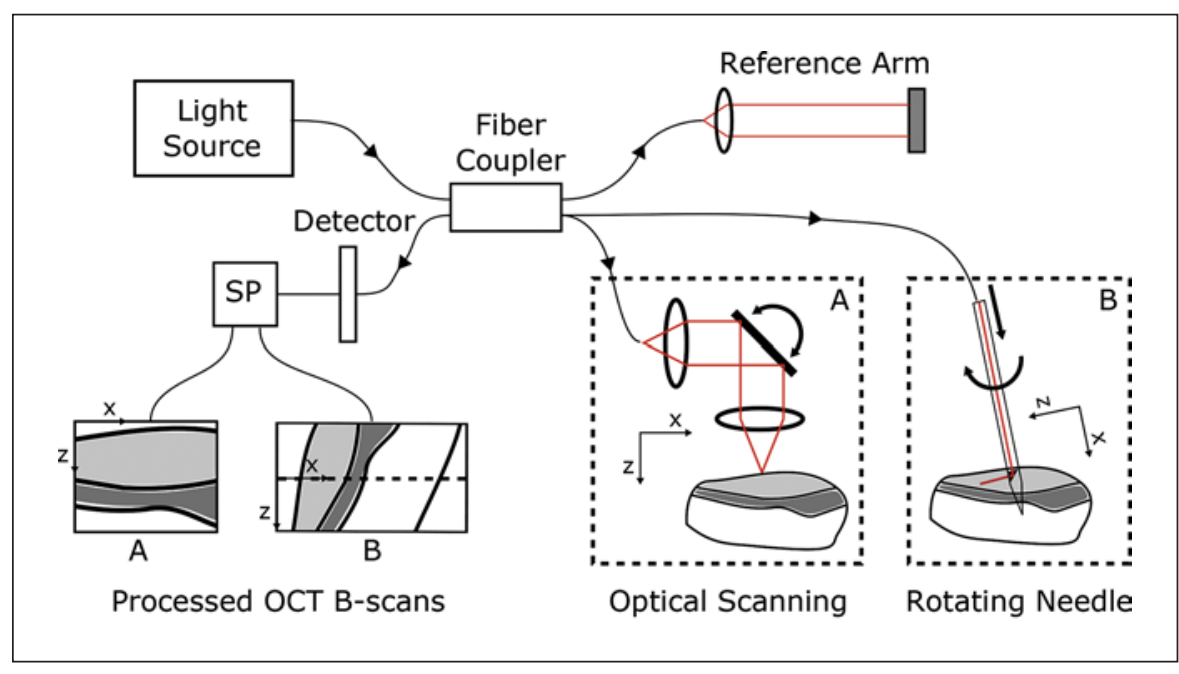

There are various OCT devices deployed for intraoperative imaging. Portable handheld devices enable an ergonomic and flexible application of non-invasive crosssectional OCT imaging in several intraoperative use cases [22]. Optical scanners (Fig. 2A) are embedded in these devices with a forward-imaging [23] or side-viewing [24] orientation. In addition, microscope-integrated OCT devices are commercially available and enable non-invasive $3 \mathrm{D}$ or even $4 \mathrm{D}$ visualization of subsurface tissues during surgical procedures [25-27].

Due to the limited penetration depth of OCT, customized optical probes are facilitated to enable image acquisitions from within the tissue. Again, optical scanners are integrated in needle probes for cross-sectional forward imaging [28]. In contrast, medical catheters [29] or needles [30] with embedded single-fibers allow for high-resolution 3D volume imaging of tissues while performing a rotation and translation of a side-viewing probe (Fig. 2B). Moreover, multifiber needle probes are facilitated for multimode imaging during punctures [31]. Multimodal tissue characterizations lead to an extensive intraoperative analysis. OCT and near infrared imaging complement each other in tumor studies [32]. Further studies proclaim the combination of high-speed OCT imaging and multispectral imaging in endoscopes [33].

\section{OCT Application in Visceral Surgery}

The most common applications of OCT are ophthalmology and ophthalmic surgery where conventional operating microscopes often provide a limited view [34]. Here, OCT has been shown to be beneficial by providing a cross-sectional view of the eye using optical scanning [35-37]. OCT has also been used for tissue characterization, for example for the detection of age-related macular degeneration [38] or glaucoma [39], which has also been studied with automatic deep learning methods [40, 41].
Another major OCT application is percutaneous coronary intervention with intravascular OCT (IVOCT), in which the artery is scanned with a rotating needle probe. The images can be used for identifying plaque deposits [42] and imaging microstructures such as high-risk thincapped fibroatheroma in the arterial wall $[43,44]$. Automated tissue characterization for decision support during interventions has also been studied using deep learning methods $[45,46]$.

So far, OCT has not been extensively used in visceral surgery. However, there have been numerous studies exploring the use of OCT in this context. For example, healthy and malignant tissue extracted from the gastrointestinal tract has been analyzed with OCT and correlated with histological findings in ex vivo analyses [47, 48]. Also, in vivo experiments in the gastrointestinal tract have been performed with a flexible OCT probe [49]. The authors concluded that an "optical biopsy" might be feasible with OCT. Similarly, Pfau et al. [50] found that in vivo OCT scans of colon adenomas, hyperplastic polyps, and normal colon tissue can be distinguished by medical experts. More recently, 3D OCT systems have been employed where imaging is performed with pullbacks, similar to IVOCT [51]. Intraperitoneal OCT imaging has also been explored, although Cahill et al. [52] concluded that confident diagnosis based on the obtained OCT signal was not feasible.

Similar to other applications, automatic tissue analysis with OCT could improve diagnostic performance and benefit the physician during interventions. For typical endoscopic videos, automated in vivo polyp detection and classification has been studied using deep learning methods [53]. For OCT, in vivo studies for automated assessment are still rare [54]. However, ex vivo studies have shown that there are measurable features that could help colon cancer classification [55]. 
Fig. 3. Principle of confocal microscopy. A Transmitted light approach patented by M. Minsky in 1957. Light from a photon source is focused onto a pinhole $(\mathrm{A})$. The condenser lens focuses the light to a spot (B) within the specimen. Light, which passes the specimen, is focused by an objective lens at a second pinhole $(\mathrm{C})$. Points $\mathrm{A}, \mathrm{B}$, and $\mathrm{C}$ are in conjugate (confocal) focus. The path of out-of-focus light is represented by the red lines and is rejected and not transmitted to the detector. B Epi-illumination setup of modern confocal laser scanning microscope. AOTF, acousto-optic tunable filters; PMT, photomultiplier tube detectors.

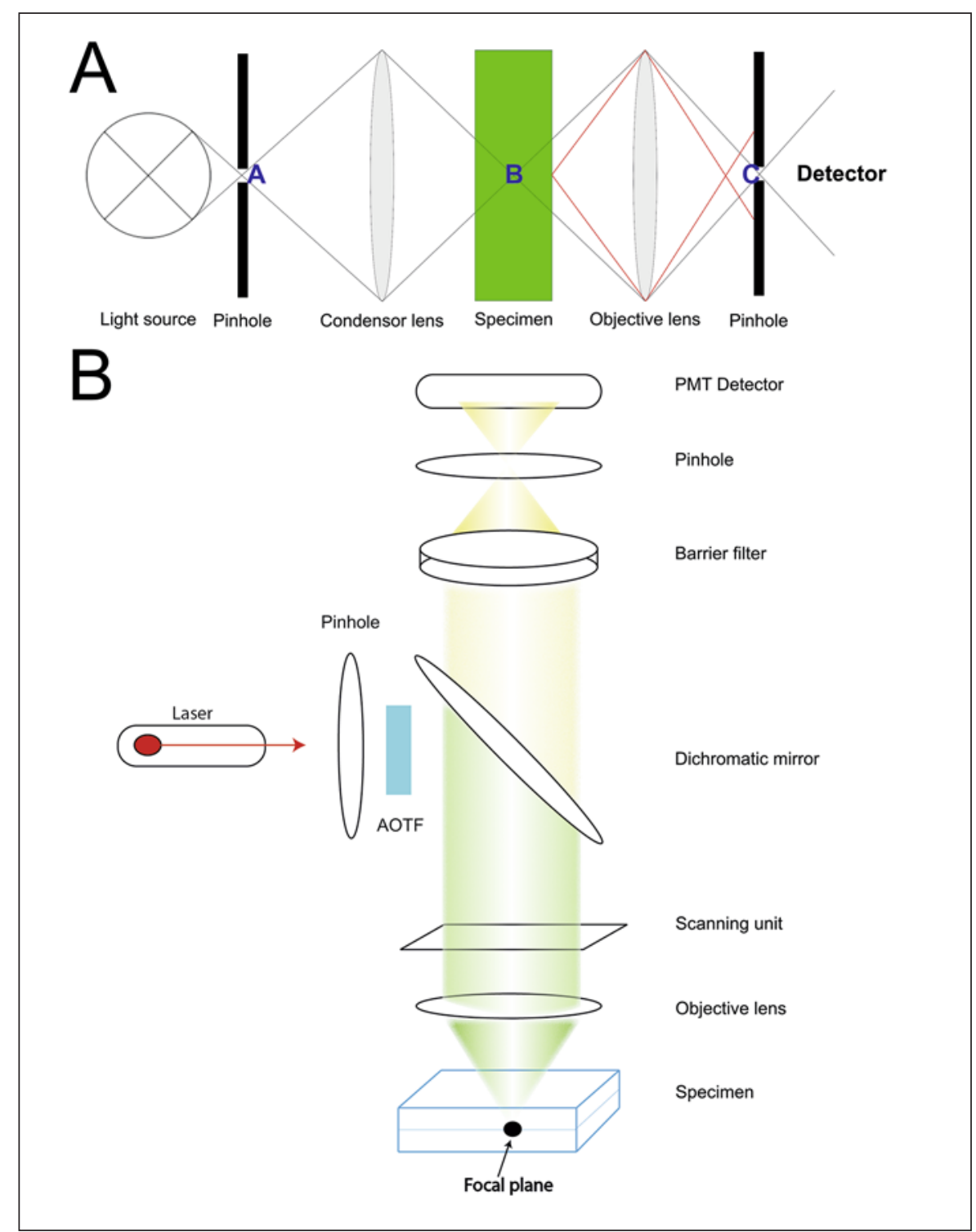

Furthermore, OCT has been explored in the context of prostate cancer. Needle-based OCT volume imaging has been used for ex vivo tissue analysis [56]. The signal attenuation allowed for the distinction of benign and malignant colon tissue, suggesting that an optical biopsy might be feasible. Similar results have been obtained using full-field OCT instead of a needle-based approach [57]. While results appear to be promising, fully automated diagnosis, for example using deep learning, has not been studied so far.

Moreover, bladder cancer has been studied using endoscopic OCT systems [58]. Recently, automated tissue layer segmentation using deep learning has been presented, suggesting that in vivo decision support might be feasible [59].

OCT has also been employed with other organs for tissue characterization and the possibility of performing an optical biopsy. Typical examples include interventions for breast cancer [30,60], lung cancer [61, 62], brain tumors $[63,64]$, and lesions in the upper aerodigestive tract [65, 66]. For most applications, automatic tissue characterization has been studied, for example using deep learning for classifying A-scans from a needle probe in the context of breast [67], lung [68], and brain [69] tissue. Also, B-scans were automatically classified for lesion characterization in the upper aerodigestive tract [70]. A comprehensive overview of more applications is given by van Manen et al. [71].

To summarize, the application of OCT for tissue analysis has been studied for multiple organs. There have been promising studies for visceral surgery; however, application during interventions is still lacking. Recently, automated tissue characterization with OCT and deep learning has demonstrated initial success, suggesting that an optical biopsy during interventions might be feasible for some applications. 
Table 1. eCLM used in visceral surgery studies $[121,122]$ in comparison to an interoperative OCT system [22]

\begin{tabular}{llll}
\hline & Optiscan/Pentax & $\begin{array}{l}\text { Cellvizio (Mauna Kea } \\
\text { Technologies) }\end{array}$ & iOCT (Haag-Streit) \\
\hline $\begin{array}{lll}\text { Type } \\
\text { Wavelength, } \mathrm{nm}\end{array}$ & $\begin{array}{l}\text { Endoscope based } \\
488 \text { and } 790\end{array}$ & $\begin{array}{l}\text { Probe based } \\
488 \text { and } 660\end{array}$ & $\begin{array}{l}\text { Probe based (SD-OCT) } \\
830\end{array}$ \\
Frame rate & $0.8 \mathrm{fps}(1,024 \times 1,024$ pixels) & $9-12 \mathrm{fps}$ (up to $40 \mathrm{fps})$ & 35,000 A-scans/s \\
Lateral resolution, $\mu \mathrm{m}$ & $1.6 \mathrm{fps}(1,024 \times 512$ pixels) & & $\begin{array}{l}\text { Dependent on NA } \\
\text { A-scan depth: } 3.8 \mathrm{~mm}^{\mathrm{b}}\end{array}$ \\
Axial resolution, $\mu \mathrm{m}$ & 0.7 & $1.4-3.5^{\mathrm{a}}$ & $5^{\mathrm{b}}$ \\
FOV, $\mu \mathrm{m}$ & 7 & $10-70^{\mathrm{a}}$ & $5,000 \times 5,000$ to $30,000 \times 30,000$ \\
Working distance, $\mu \mathrm{m}$ & $475 \times 475$ & $240 \times 240$ to $600 \times 500^{\mathrm{a}}$ & 175,000 \\
Distal tip diameter, $\mathrm{mm}$ & 250 & $0-10^{\mathrm{a}}$ & \\
\hline
\end{tabular}

FOV, field of view; fps, frames per second; NA, numerical aperture of the lens.

${ }^{a}$ Depending on confocal microprobe. ${ }^{b}$ Specified in air.

\section{Confocal Laser Microscopy}

Historical Perspective and Principle of CLM

After the establishment of microscopy as an important part of biological and medical research, microscopists soon noticed that scattered light from unfocussed areas of a specimen decreased the image quality. Especially for an increasing thickness of specimen, scattered out-of-focus light has a negative effect on image contrast. Therefore, the need to examine tissue without interference from outof-focus light, and additionally in vivo, was the driving force behind the development of confocal microscopy [72].

The first confocal microscope is generally credited to Marvin Minsky from 1955. In 1957, he filed the first confocal microscope patent [73, 74]. Twelve years later, Davidovits and Egger [75] published the first application of a confocal laser microscope. However, it took until the mid-1980s for CLM to achieve its breakthrough, benefited by several major technological advances, such as bright and stable laser light sources or software for analyzing the images [74]. White, Amos, and Fordham [76] built the first confocal laser scanning microscope. Offering some advantages compared to the conventional fluorescence microscopy, CLM became a cornerstone of biomedical research $[77,78]$. Due to its excellent lateral resolution and increased contrast, CLM made it possible to examine single cells or specific molecules within a cell ex vivo as well as in vivo [76, 79].

Scanning a point source of light across the specimen and using a pinhole, elimination of out-of-focus light is the key to the confocal approach [74]. Minsky [73] described a transmitted light approach of CLM in his patent: emitted light from a light source is bundled by the pinhole and focused by a condenser lens into the specimen. The light, which passes through the specimen, is focused by the objective lens onto another pinhole. Points A, B, and $\mathrm{C}$ are in conjugate (confocal) focus. Out-of-focus light does not reach the detector (Fig. 3A) [73, 74, 80]. Figure $3 \mathrm{~B}$ shows the setup of a modern confocal laser scanning microscope using acousto-optic tunable filters, a dichroic mirror, and photomultiplier tube detectors.

Most visceral surgery studies dealing with CLM are based on two commercially available confocal endomicroscopy systems (Table 1). A general handicap of eCLM is the application of intravenous or topical fluorescent agents to achieve contrast. We evaluated a CLM device developed for a minimal-invasive surgical approach and intraoperative diagnostics that does not need any fluorescent contrast dye. The endoscope CLM system consists of a modified Rostock Cornea module of the Heidelberg Engineering Retina Tomograph II HRT II (Heidelberg Engineering GmbH, Heidelberg, Germany) and a specially developed rigid endoscope (Karls Storz SE \& Co. KG, Tuttlingen, Germany; Fig. 4). The light source is a $670-\mathrm{nm}$ diode laser. The circular scan field is $300 \times 300 \mu \mathrm{m}$ with a maximum lateral and axial resolution of 1-2 $\mu \mathrm{m}$. The penetration depth $(z-$ axis) is between 100 and $450 \mu \mathrm{m}$ depending on the tissue. The scan rate is $40 \mathrm{frames} / \mathrm{s}[9,81,82]$. The special feature of this CLM device is that it does not require any fluorescent dye. Induced fluorescence of the tissue alone is sufficient for imaging. Introduced through a laparoscopic or thoracoscopic port, surgeons can use the CLM camera device like any other surgical instrument $[9,83]$.

\section{CLM Applications in Visceral Surgery}

Already a few years after the first commercially available CLM devices were introduced, CLM was applied in clinical settings. CLM was used to examine the cornea and retina by ophthalmologists [84-87], and dermatolo- 


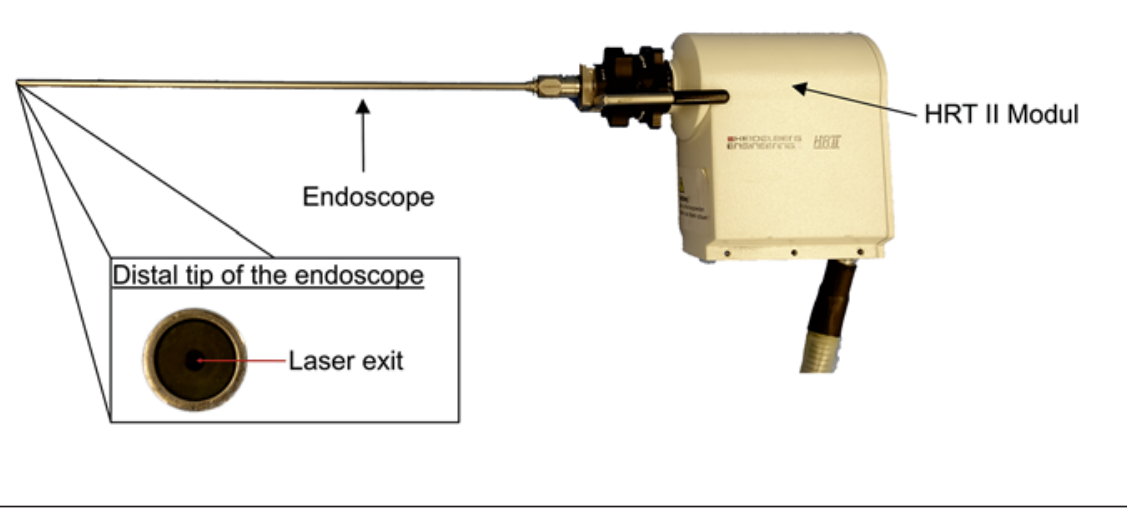

Fig. 4. Prototype of an endoscopic CLM device.

gists implemented CLM in their skin cancer and autoinflammation diagnostics $[88,89]$. The clinical application of CLM as confocal laser endomicroscopy (eCLM) started in 2004 with the in vivo diagnosis of intraepithelial neoplasia and colorectal cancer [90]. Since then, eCLM has established itself as an integral part of endoluminal diagnostics in gastroenterology [91-99]. The eCLM was also evaluated in urology and pneumology $[100,101]$.

Examining resection margins, CLM devices were used for intraoperative optical biopsy in breast surgery [102] and in brain tumor surgery [103-105]. The first steps for the intraoperative application of CLM were performed in pilot studies, in vivo in animal models or ex vivo on human tissue in visceral surgery. Several animal studies showed that in vivo tissue examination is safe and feasible [106-110]. Schneider et al. [110] showed that CLM enables the user to distinguish between normal and metastatic liver tissue in an orthotopic murine model of colorectal cancer liver metastasis. Mennone and Nathanson [108] demonstrated that it is feasible to distinguish normal from cirrhotic liver tissue. In 2008, Goetz et al. [111] performed the first in vivo intraoperative liver tissue examination during laparoscopy. Twenty-five patients with liver disease were examined during routine minilaparoscopy. The authors found that confocal diagnosis of moderate-to-severe steatosis and pericellular fibrosis correlated well with histopathologic analysis of subsequent biopsies. Fuks et al. [112] published their results in 2019, showing that the sensitivity and specificity of in vivo intraoperative tissue examination were 67 and 100\% for peritoneal and 38 and 100\% for hepatic carcinogenesis, respectively. Using CLM ex vivo during renal cancer surgery, a further study showed that it is possible to distinguish normal from cancer tissue [113]. The Needle-Based, In Vivo Feasibility Study is going to evaluate CLM for prostatic cancer diagnosis [114]. Risi et al. [115] and Chene et al. [116] showed that optical biopsy by CLM enables the differentiation between normal and malignant tissue in tubal lesions and ovarian surface epithelium. In a recent study, we were able to show that the CLM system described above not only enables tissue examination [9], but also differentiates between benign and malignant colon and peritoneal tissue, respectively [83]. A correlation between primary cancer lesions and metastasis was also achieved [83].

A general limitation of CLM is the low tissue penetration depth $(100-450 \mu \mathrm{m})$. As a result, the abdominal organs can only be examined superficially. In addition, the different CLM patterns of the various tumor entities might confront the surgeon with enormous intraoperative difficulties in dealing with the surgical procedure and tissue identification. The solution could be the intraoperative support of the surgeon by a computer-assisted image analysis using deep learning strategies. Several studies have shown the application of deep learning strategies in CLM tumor identification of brain tumors, melanoma, and oral cavity cancer [14, 117-119]. In a recent study, we were able to show that deep learning can differentiate between cancer and healthy tissue [120]. However, deep learning is still in its incipient stages in visceral surgery tissue classification.

\section{Conclusion}

OCT and CLM do not yet represent a standard for intraoperative tissue analysis. Recent study results show that these are two promising methods of intraoperative in vivo and real-time tissue examination. However, further studies are needed to further develop OCT and CLM for the application in visceral surgery. In this context, it should be considered that these procedures are not competing but complementary approaches of tissue analysis to intraoperative frozen section analysis.

While still lacking intraoperative application, automated tissue analysis, in particular using deep learning methods, has gained popularity both for OCT and CLM. 
Providing immediate visualization of tissue boundaries and properties could greatly benefit surgeons during interventions.

\section{Statement of Ethics}

Ethical considerations were not applicable to this review.

\section{Disclosure Statement}

The authors have no known conflicts of interest associated with this study and there has been no significant financial support for this work that could have influenced its outcome.

\section{Funding Sources}

Dr. David B. Ellebrecht received a junior research grant from the University of Lübeck for the study "Confocal laser microscopy as novel approach for real-time and in-vivo tissue examination during minimal-invasive surgery in colon cancer" (J02-2015).

\section{Author Contributions}

D.B.E., S.L., and N.G. contributed to the conception and design, and drafting and revision of the article. A.S. and T.K. contributed to drafting and revision of the article. All authors provided final approval of the version submitted.

\section{References}

1 Dagenais GR, Leong DP, Rangarajan S, Lanas F, Lopez-Jaramillo P, Gupta R, et al. Variations in common diseases, hospital admissions, and deaths in middle-aged adults in 21 countries from five continents (PURE): a prospective cohort study. Lancet. 2019 Sep;S0140-6736(19)32007-0.

2 Bray F, Ferlay J, Soerjomataram I, Siegel RL, Torre LA, Jemal A. Global cancer statistics 2018: GLOBOCAN estimates of incidence and mortality worldwide for 36 cancers in 185 countries. CA Cancer J Clin. 2018 Nov;68(6): 394-424.

3 WHO [Internet]. The Top 10 Causes of Death. 2018 [cited 2020 Feb 24]. Available from: https://www.who.int/news-room/factsheets/detail/the-top-10-causes-of-death.

4 WHO [Internet]. Cancer. 2019 [cited 2020 Feb 24]. Available from: https://www.who. int/news-room/fact-sheets/detail/cancer.

5 Stewart BW, Wild CP, editors. World cancer report. Lyon: IARC Press; 2014.

6 Balog J, Sasi-Szabó L, Kinross J, Lewis MR, Muirhead LJ, Veselkov K, et al. Intraoperative tissue identification using rapid evaporative ionization mass spectrometry. Sci Transl Med. 2013 Jul;5(194):194ra93.

7 Wibe A, Rendedal PR, Svensson E, Norstein J, Eide TJ, Myrvold HE, et al. Prognostic significance of the circumferential resection margin following total mesorectal excision for rectal cancer. Br J Surg. 2002 Mar;89(3): 327-34.

8 Westgaard A, Tafjord S, Farstad IN, Cvancarova M, Eide TJ, Mathisen O, et al. Resectable adenocarcinomas in the pancreatic head: the retroperitoneal resection margin is an independent prognostic factor. BMC Cancer. 2008 Jan;8(1):5.

9 Ellebrecht DB, Gebhard MP, Horn M, Keck T, Kleemann M. Laparoscopic Confocal Laser Microscopy Without Fluorescent Injection: A Pilot Ex Vivo Study in Colon Cancer. Surg Innov. 2016 Aug;23(4):341-6.

10 Crawshaw B, Delaney CP. Gastrointestinal surgery: real-time tissue identification during surgery. Nat Rev Gastroenterol Hepatol. 2013 Nov;10(11):624-5.

11 Reinhart MB, Huntington CR, Blair LJ, Heniford BT, Augenstein VA. Indocyanine Green: Historical context, current applications, and future considerations. Surg Innov. 2016; 23(2):166-75.

12 Darin MC, Gómez-Hidalgo NR, Westin SN, Soliman PT, Escobar PF, Frumovitz M, et al. Role of Indocyanine Green in Sentinel Node Mapping in Gynecologic Cancer: Is Fluorescence Imaging the New Standard? J Minim Invasive Gynecol. 2016 Feb;23(2):186-93.

13 Kataoka F, Susumu N, Yamagami W, Kuwahata $\mathrm{M}$, Takigawa A, Nomura $\mathrm{H}$, et al. The importance of para-aortic lymph nodes in sentinel lymph node mapping for endometrial cancer by using hysteroscopic radio-isotope tracer injection combined with subserosal dye injection: prospective study. Gynecol Oncol. 2016 Mar;140(3):400-4.

14 Litjens G, Kooi T, Bejnordi BE, Setio AA, Ciompi F, Ghafoorian M, et al. A survey on deep learning in medical image analysis. Med Image Anal. 2017 Dec;42:60-88.

15 Yeow JT, Yang VX, Chahwan A, Gordon ML, Qi B, Vitkin IA, et al. Micromachined 2-D scanner for 3-D optical coherence tomography. Sens Actuators A Phys. 2005;117(2):331-40.

16 Singh AS, Kolbitsch C, Schmoll T, Leitgeb RA. Stable absolute flow estimation with Doppler OCT based on virtual circumpapillary scans. Biomed Opt Express. 2010 Oct;1(4):1047-58.

17 Finke M, Kantelhardt S, Schlaefer A, Bruder R, Lankenau E, Giese A, et al. Automatic scanning of large tissue areas in neurosurgery using optical coherence tomography. Int J Med Robot. 2012 Sep;8(3):327-36.

18 Latus S, Otte C, Schlüter M, Rehra J, Bizon K, Schulz-Hildebrandt $\mathrm{H}$, et al. An Approach for Needle Based Optical Coherence Elastography Measurements. Cham: Springer International Publishing; 2017. pp. 655-63.

19 Nadiarnykh O, Davidoiu V, Gräfe MG, Bosscha M, Moll AC, de Boer JF. Phase-based OCT angiography in diagnostic imaging of pediatric retinoblastoma patients: abnormal blood vessels in post-treatment regression patterns. Biomed Opt Express. 2019 Apr; 10(5):2213-26.

20 Choma M, Sarunic M, Yang C, Izatt J. Sensitivity advantage of swept source and Fourier domain optical coherence tomography. Opt Express. 2003 Sep;11(18):2183-9.

21 Kolb JP, Pfeiffer T, Eibl M, Hakert H, Huber R. High-resolution retinal swept source opti- cal coherence tomography with an ultrawideband Fourier-domain mode-locked laser at $\mathrm{MHz} \mathrm{A}$-scan rates. Biomed Opt Express. 2017 Dec;9(1):120-30.

22 Monroy GL, Won J, Spillman DR, Dsouza R, Boppart SA. Clinical translation of handheld optical coherence tomography: practical considerations and recent advancements. J Biomed Opt. 2017 Dec;22(12):1-30.

23 Zysk AM, Chen K, Gabrielson E, Tafra L, May Gonzalez EA, Canner JK, et al. Intraoperative Assessment of Final Margins with a Handheld Optical Imaging Probe During Breast-Conserving Surgery May Reduce the Reoperation Rate: Results of a Multicenter Study. Ann Surg Oncol. 2015 Oct;22(10):3356-62.

24 Benboujja F, Garcia JA, Beaudette K, Strupler M, Hartnick CJ, Boudoux C. Intraoperative imaging of pediatric vocal fold lesions using optical coherence tomography. J Biomed Opt. 2016 Jan;21(1):16007.

25 Haag-Streit Surgical iOCT Product Description.

26 Leica Microsystems OCT Systems for Ophthalmology.

27 Zeiss OPMI Lumera 7000. Jena; 2019.

28 Liang CP, Wierwille J, Moreira T, Schwartzbauer G, Jafri MS, Tang CM, et al. A forwardimaging needle-type OCT probe for image guided stereotactic procedures. Opt Express. 2011 Dec;19(27):26283-94.

29 Wang T, Pfeiffer T, Regar E, Wieser W, van Beusekom H, Lancee CT, et al. Heartbeat OCT and Motion-Free 3D In Vivo Coronary Artery Microscopy. JACC Cardiovasc Imaging. 2016 May;9(5):622-3.

30 McLaughlin RA, Quirk BC, Curatolo A, Kirk RW, Scolaro L, Lorenser D, et al. Imaging of breast cancer with optical coherence tomography needle probes: feasibility and initial results. IEEE J Sel Top Quantum Electron. 2012; 18(3):1184-91.

31 Holt D, Singhal S, Selmic LE. Near-infrared imaging and optical coherence tomography for intraoperative visualization of tumors. Vet Surg. 2020;49(1):33-43.

32 Lorenser D, Quirk BC, Auger M, Madore WJ, Kirk RW, Godbout N, et al. Dual-modality needle probe for combined fluorescence imaging and three-dimensional optical coherence tomography. Opt Lett. 2013 Feb;38(3):266-8. 
33 Göb M, Pfeiffer T, Huber R. Towards combined optical coherence tomography and multi-spectral imaging with $\mathrm{MHz}$ A-scan rates for endoscopy. In: Boppart SA, Wojtkowski M, Oh W-Y, editors. Optical coherence imaging techniques and imaging in scattering media III. SPIE; 2019. p. 33.

34 Steven P, Le Blanc C, Velten K, Lankenau E, Krug M, Oelckers S, et al. Optimizing descemet membrane endothelial keratoplasty using intraoperative optical coherence tomography. JAMA Ophthalmol. 2013 Sep;131(9): 1135-42.

35 Binder S, Falkner-Radler CI, Hauger C, Matz $\mathrm{H}$, Glittenberg C. Feasibility of intrasurgical spectral-domain optical coherence tomography. Retina. 2011 Jul-Aug;31(7):1332-6.

36 Ehlers JP, Kernstine K, Farsiu S, Sarin N, Maldonado R, Toth CA. Analysis of pars plana vitrectomy for optic pit-related maculopathy with intraoperative optical coherence tomography: a possible connection with the vitreous cavity. Arch Ophthalmol. 2011;129(11): 1483-86.

37 Ehlers JP, Tam T, Kaiser PK, Martin DF, Smith GM, Srivastava SK. Utility of intraoperative optical coherence tomography during vitrectomy surgery for vitreomacular traction syndrome. Retina. 2014 Jul;34(7):1341-6.

38 Fleckenstein M, Charbel Issa P, Helb HM, Schmitz-Valckenberg S, Finger RP, Scholl $\mathrm{HP}$, et al. High-resolution spectral domainOCT imaging in geographic atrophy associated with age-related macular degeneration. Invest Ophthalmol Vis Sci. 2008 Sep;49(9): 4137-44.

39 Bussel II, Wollstein G, Schuman JS. OCT for glaucoma diagnosis, screening and detection of glaucoma progression. Br J Ophthalmol. 2014 Jul;98 Suppl 2:ii15-9.

40 Lee CS, Baughman DM, Lee AY. Deep learning is effective for the classification of OCT images of normal versus Age-related Macular Degeneration. Ophthalmol Retina. 2017 JulAug;1(4):322-7.

41 Muhammad H, Fuchs TJ, De Cuir N, De Moraes CG, Blumberg DM, Liebmann JM, et al. Hybrid Deep Learning on Single Widefield Optical Coherence tomography Scans Accurately Classifies Glaucoma Suspects. J Glaucoma. 2017 Dec;26(12):1086-94.

42 Tearney GJ, Regar E, Akasaka T, Adriaenssens T, Barlis P, Bezerra HG, et al. Consensus standards for acquisition, measurement, and reporting of intravascular optical coherence tomography studies: a report from the International Working Group for Intravascular Optical Coherence Tomography Standardization and Validation. J Am Coll Cardiol. 2012 Mar;59(12):1058-72.

43 Phipps JE, Hoyt T, Vela D, Wang T, Michalek JE, Buja LM, et al. Diagnosis of Thin-Capped Fibroatheromas in Intravascular Optical Coherence Tomography Images: Effects of Light Scattering. Circ Cardiovasc Interv. 2016 Jul; 9(7):e003163.

44 Kini AS, Vengrenyuk Y, Yoshimura T, Matsumura M, Pena J, Baber U, et al. Fibrous Cap Thickness by Optical Coherence Tomography In Vivo. J Am Coll Cardiol. 2017 Feb; 69(6):644-57.
45 Kolluru C, Prabhu D, Gharaibeh Y, Bezerra H, Guagliumi G, Wilson D. Deep neural networks for A-line-based plaque classification in coronary intravascular optical coherence tomography images. J Med Imaging (Bellingham). 2018 Oct;5(4):044504.

46 Gessert N, Lutz M, Heyder M, Latus S, Leistner DM, Abdelwahed YS, et al. Automatic Plaque Detection in IVOCT Pullbacks Using Convolutional Neural Networks. IEEE Trans Med Imaging. 2019 Feb;38(2):426-34.

47 Kobayashi K, Izatt JA, Kulkarni MD, Willis J, Sivak MV Jr. High-resolution cross-sectional imaging of the gastrointestinal tract using optical coherence tomography: preliminary results. Gastrointest Endosc. 1998 Jun;47(6): 515-23.

48 Pitris C, Jesser C, Boppart SA, Stamper D, Brezinski ME, Fujimoto JG. Feasibility of optical coherence tomography for high-resolution imaging of human gastrointestinal tract malignancies. J Gastroenterol. 2000;35(2): 87-92.

49 Jäckle S, Gladkova N, Feldchtein F, Terentieva A, Brand B, Gelikonov G, et al. In vivo endoscopic optical coherence tomography of the human gastrointestinal tract-toward optical biopsy. Endoscopy. 2000 Oct;32(10): 743-9.

50 Pfau PR, Sivak MV Jr, Chak A, Kinnard M, Wong RC, Isenberg GA, et al. Criteria for the diagnosis of dysplasia by endoscopic optical coherence tomography. Gastrointest Endosc. 2003 Aug;58(2):196-202.

51 Adler DC, Zhou C, Tsai TH, Lee HC, Becker L, Schmitt JM, et al. Three-dimensional optical coherence tomography of Barrett's esophagus and buried glands beneath neosquamous epithelium following radiofrequency ablation. Endoscopy. 2009 Sep;41(9):773-6.

52 Cahill RA, Asakuma M, Trunzo J, Schomisch S, Wiese D, Saha S, et al. Intraperitoneal virtual biopsy by fibered optical coherence tomography (OCT) at natural orifice transluminal endoscopic surgery (NOTES). J Gastrointest Surg. 2010 Apr;14(4):732-8.

53 Ribeiro E, Uhl A, Wimmer G, Häfner M. Exploring deep learning and transfer learning for colonic polyp classification. Comput Math Methods Med. 2016;2016:6584725.

54 Samel NS, Mashimo H. Application of OCT in the gastrointestinal tract. Appl Sci. 2019; 9(15):2991.

55 Zhao Q, Zhou C, Wei H, He Y, Chai X, Ren $\mathrm{Q}$. Ex vivo determination of glucose permeability and optical attenuation coefficient in normal and adenomatous human colon tissues using spectral domain optical coherence tomography. J Biomed Opt. 2012 Oct;17(10): 105004.

56 Muller BG, de Bruin DM, Brandt MJ, van den Bos W, van Huystee S, Faber DJ, et al. Prostate cancer diagnosis by optical coherence tomography: first results from a needle based optical platform for tissue sampling. J Biophotonics. 2016 May;9(5):490-8.

57 Lopater J, Colin P, Beuvon F, Sibony M, Dalimier E, Cornud F, et al. Real-time cancer diagnosis during prostate biopsy: ex vivo evaluation of full-field optical coherence tomography (FFOCT) imaging on biopsy cores. World J Urol. 2016 Feb;34(2):237-43.
58 Jesser CA, Boppart SA, Pitris C, Stamper DL, Nielsen GP, Brezinski ME, et al. High resolution imaging of transitional cell carcinoma with optical coherence tomography: feasibility for the evaluation of bladder pathology. $\mathrm{Br}$ J Radiol. 1999 Dec;72(864):1170-6.

59 Li A, Congwu D, Pan Y. Automated layer segmentation of bladder OCT images for enhanced detection of transitional cell carcinoma. In: Fujimoto JG, Izatt JA, editors. Optical coherence tomography and coherence domain optical methods in biomedicine XXIII. SPIE; 2019. pp. 36-43.

60 Nguyen FT, Zysk AM, Chaney EJ, Adie SG, Kotynek JG, Oliphant UJ, et al. Optical coherence tomography: The intraoperative assessment of lymph nodes in breast cancer. IEEE engineering in medicine and biology magazine : the quarterly magazine of the Engineering in Medicine \&. Biol Soc. 2010;29(2):6370 .

61 Lam S, Standish B, Baldwin C, McWilliams A, leRiche J, Gazdar A, et al. In vivo optical coherence tomography imaging of preinvasive bronchial lesions. Clin Cancer Res. 2008; 14(7):2006-11.

62 Michel RG, Kinasewitz GT, Fung KM, Keddissi JI. Optical coherence tomography as an adjunct to flexible bronchoscopy in the diagnosis of lung cancer: a pilot study. Chest. 2010 Oct;138(4):984-8.

63 Böhringer HJ, Boller D, Leppert J, Knopp U, Lankenau E, Reusche E, et al. Time-domain and spectral-domain optical coherence tomography in the analysis of brain tumor tissue. Lasers Surg Med. 2006 Jul;38(6):588-97.

64 Kut C, Chaichana KL, Xi J, Raza SM, Ye X, $\mathrm{McVeigh} \mathrm{ER}$, et al. Detection of human brain cancer infiltration ex vivo and in vivo using quantitative optical coherence tomography. Sci Transl Med. 2015 Jun;7(292):292ra100.

65 Volgger V, Stepp H, Ihrler S, Kraft M, Leunig A, Patel PM, et al. Evaluation of optical coherence tomography to discriminate lesions of the upper aerodigestive tract. Head Neck. 2013 Nov;35(11):1558-66.

66 Panta P, Chih-Wei L, Piyush K, Tuan-Shu H, Sheng-Lung H, Pawan K, et al. Optical coherence tomography: emerging in vivo optical biopsy technique for oral cancers. In: Panta P, editor. Oral cancer detection: novel strategies and clinical impact. Cham: Springer International Publishing; 2019. pp. 217-37.

67 Mojahed D, Ha RS, Chang P, Gan Y, Yao X, Angelini B, et al. Fully Automated Postlumpectomy Breast Margin Assessment Utilizing Convolutional Neural Network Based Optical Coherence Tomography Image Classification Method. Acad Radiol. 2019 Jul;S1076-6332(19)30324-1.

68 Otte C, Otte S, Wittig L, Hüttmann G, Kugler $\mathrm{C}$, Drömann $\mathrm{D}$, et al. Investigating recurrent neural networks for OCT A-scan based tissue analysis. Methods Inf Med. 2014;53(4):245-9.

69 Lenz M, Krug R, Dillmann C, Stroop R, Gerhardt NC, Welp H, et al. Automated differentiation between meningioma and healthy brain tissue based on optical coherence tomography ex vivo images using texture features. J Biomed Opt. 2018 Feb;23(7):1-7. 
70 Gessert N, Schlüter M, Latus S, Volgger V, Betz CS, Schlaefer A. Towards automatic lesion classification in the upper aerodigestive tract using OCT and deep transfer learning methods. Int J CARS. 2019;14 Suppl 1:180-1.

71 van Manen L, Dijkstra J, Boccara C, Benoit E, Vahrmeijer AL, Gora MJ, et al. The clinical usefulness of optical coherence tomography during cancer interventions. J Cancer Res Clin Oncol. 2018 Oct;144(10):1967-90.

72 Berek M. Grundlagen der Tiefenwahrnehmung im Mikroskop: mit einem Anhang über die Bestimmung der obersten Grenze des unvermeidlichen Fehlers einer Messung aus der Häufigkeitsverteilung der zufälligen Maximalfehler. Marburg: S.-B. Ges. Naturw; 1927.

73 Minsky M. Microscopy apparatus. 1957.

74 Paddock SW, Eliceiri KW. Laser scanning confocal microscopy: history, applications, and related optical sectioning techniques. Methods Mol Biol. 2014;1075:9-47.

75 Davidovits P, Egger MD. Scanning laser microscope. Nature. 1969 Aug;223(5208):831.

76 White JG, Amos WB, Fordham M. An evaluation of confocal versus conventional imaging of biological structures by fluorescence light microscopy. J Cell Biol. 1987 Jul;105(1): 41-8.

77 Robinson JP. Principles of confocal microscopy. Methods Cell Biol. 2001;63:89-106.

78 Halbhuber KJ, Konig K. Modern laser scanning microscopy in biology, biotechnology and medicine. Ann Anat. 2003 Jan;185(1): 120.

79 Roderfeld M, Matern S, Roeb E. [Confocal laser scanning microscopy: a deep look into the cell]. Dtsch Med Wochenschr. 2003 Nov; 128(48):2539-42

80 Price RL, Jerome WG. Introduction and Historical Perspective. In: Jerome WG, Price RL, editors. Basic Confocal Microscopy. Cham: Springer International Publishing; 2018. pp. $1-20$.

81 Farahati B, Stachs O, Prall F, Stave J, Guthoff $\mathrm{R}, \mathrm{Pau} \mathrm{HW}$, et al. Rigid confocal endoscopy for in vivo imaging of experimental oral squamous intra-epithelial lesions. J Oral Pathol Med. 2010 Apr;39(4):318-27.

82 Just T, Wiechmann T, Stachs O, Stave J, Guthoff R, Hüttmann G, et al. Confocal endomicroscopy of the larynx. Photonic Therapeut Diagn VIII. 2012;82072H. https://doi. org/10.1117/12.921265.

83 Ellebrecht DB, Kuempers C, Horn M, Keck T, Kleemann M. Confocal laser microscopy as novel approach for real-time and in-vivo tissue examination during minimal-invasive surgery in colon cancer. Surg Endosc. 2019 Jun;33(6):1811-7.

84 Webb RH, Hughes GW, Delori FC. Confocal scanning laser ophthalmoscope. Appl Opt. 1987 Apr;26(8):1492-9.

85 Cavanagh HD, Jester JV, Essepian J, Shields W, Lemp MA. Confocal microscopy of the living eye. CLAO J. 1990 Jan-Mar;16(1):6573.

86 Sharp PF, Manivannan A, Xu H, Forrester JV. The scanning laser ophthalmoscope-a review of its role in bioscience and medicine. Phys Med Biol. 2004 Apr;49(7):1085-96.
87 Erie JC, McLaren JW, Patel SV. Confocal microscopy in ophthalmology. Am J Ophthalmol. 2009 Nov;148(5):639-46.

88 Ulrich M. Confocal laser scanning microscopy. Hautarzt. 2015 Jul;66(7):504-10. German.

89 Cinotti E, Labeille B, Cambazard F, Perrot JL. Confocal Microscopy for Special Sites and Special Uses. Dermatol Clin. 2016 Oct; 34(4):477-85.

90 Kiesslich R, Burg J, Vieth M, Gnaendiger J, Enders M, Delaney P, et al. Confocal laser endoscopy for diagnosing intraepithelial neoplasias and colorectal cancer in vivo. Gastroenterology. 2004 Sep;127(3):706-13.

91 Kiesslich R, Goetz M, Burg J, Stolte M, Siegel E, Maeurer MJ, et al. Diagnosing Helicobacter pylori in vivo by confocal laser endoscopy. Gastroenterology. 2005 Jun; 128(7):2119-23.

92 Kiesslich R, Goetz M, Vieth M, Galle PR, Neurath MF. Confocal laser endomicroscopy. Gastrointest Endosc Clin N Am. 2005 Oct;15(4):715-31.

93 Hoffman A, Goetz M, Vieth M, Galle PR, Neurath MF, Kiesslich R. Confocal laser endomicroscopy: technical status and current indications. Endoscopy. 2006 Dec;38(12): 1275-83.

94 Kiesslich R, Goetz M, Angus EM, Hu Q, Guan Y, Potten C, et al. Identification of epithelial gaps in human small and large intestine by confocal endomicroscopy. Gastroenterology. 2007 Dec;133(6):1769-78.

95 Kiesslich R, Goetz M, Vieth M, Galle PR, Neurath MF. Technology insight: confocal laser endoscopy for in vivo diagnosis of colorectal cancer. Nat Clin Pract Oncol. 2007 Aug;4(8):480-90.

96 Kiesslich R, Goetz M, Neurath MF. Confocal laser endomicroscopy for gastrointestinal diseases [viii.]. Gastrointest Endosc Clin N Am. 2008 Jul;18(3):451-66.

97 De Palma GD. Confocal laser endomicroscopy in the "in vivo" histological diagnosis of the gastrointestinal tract. World J Gastroenterol. 2009 Dec;15(46):5770-5.

98 Goetz M, Watson A, Kiesslich R. Confocal laser endomicroscopy in gastrointestinal diseases. J Biophotonics. 2011 Aug;4(7-8): 498-508.

99 Fugazza A, Gaiani F, Carra MC, Brunetti F, Lévy M, Sobhani I, et al. Confocal laser endomicroscopy in gastrointestinal and pancreatobiliary diseases: a systematic review and meta-analysis. BioMed Res Int. 2016; 2016:4638683

100 Chen SP, Liao JC. Confocal laser endomicroscopy of bladder and upper tract urothelial carcinoma: a new era of optical diagnosis? Curr Urol Rep. 2014 Sep;15(9):437.

101 Streba CT, Gîltan AM, Gheonea IA, Demetrian A, Şoimu AV, Săftoiu A, et al. Utility of confocal laser endomicroscopy in pulmonology and lung cancer. Rom J Morphol Embryol. 2016;57(4):1221-7.

102 De Palma GD, Luglio G, Esposito D. Confocal laser endomicroscopy in breast surgery. Breast Cancer Res Treat. 2015 Nov;154(2): 439.
103 Foersch S, Heimann A, Ayyad A, Spoden GA, Florin L, Mpoukouvalas K, et al. Confocal laser endomicroscopy for diagnosis and histomorphologic imaging of brain tumors in vivo. PLoS One. 2012;7(7):e41760.

104 Breuskin D, Divincenzo J, Kim YJ, Urbschat S, Oertel J. Confocal laser endomicroscopy in neurosurgery: a new technique with much potential. Minim Invasive Surg. 2013; 2013:851819.

105 Martirosyan NL, Georges J, Eschbacher JM, Belykh E, Carotenuto A, Spetzler RF, et al. Confocal scanning microscopy provides rapid, detailed intraoperative histological assessment of brain neoplasms: experience with 106 cases. Clin Neurol Neurosurg. 2018 Jun;169:21-8.

106 von Delius S, Feussner H, Wilhelm D, Karagianni A, Henke J, Schmid RM, et al. Transgastric in vivo histology in the peritoneal cavity using miniprobe-based confocal fluorescence microscopy in an acute porcine model. Endoscopy. 2007 May;39(5):407-11.

107 Becker V, Wallace MB, Fockens P, von Delius S, Woodward TA, Raimondo M, et al. Needle-based confocal endomicroscopy for in vivo histology of intra-abdominal organs: first results in a porcine model (with videos). Gastrointest Endosc. 2010 Jun;71(7): 1260-6.

108 Mennone A, Nathanson MH. Needle-based confocal laser endomicroscopy to assess liver histology in vivo. Gastrointest Endosc. 2011 Feb;73(2):338-44

109 Hara H, Takahashi T, Nakatsuka R, Higashi S, Naka T, Sumiyama K, et al. A novel approach of optical biopsy using probe-based confocal laser endomicroscopy for peritoneal metastasis. Surg Endosc. 2016 Aug; 30(8):3437-46.

110 Schneider C, Johnson SP, Gurusamy K, Cook RJ, Desjardins AE, Hawkes DJ, et al. Identification of liver metastases with probe-based confocal laser endomicroscopy at two excitation wavelengths. Lasers Surg Med. 2017 Mar;49(3):280-92.

111 Goetz M, Kiesslich R, Dienes HP, Drebber U, Murr E, Hoffman A, et al. In vivo confocal laser endomicroscopy of the human liver: a novel method for assessing liver microarchitecture in real time. Endoscopy. 2008 Jul;40(7):554-62.

112 Fuks D, Pierangelo A, Validire P, Lefevre M, Benali A, Trebuchet G, et al. Intraoperative confocal laser endomicroscopy for realtime in vivo tissue characterization during surgical procedures. Surg Endosc. 2019 May;33(5):1544-52.

113 Su LM, Kuo J, Allan RW, Liao JC, Ritari KL, Tomeny PE, et al. Fiber-Optic Confocal Laser Endomicroscopy of Small Renal Masses: Toward Real-Time Optical Diagnostic Biopsy. J Urol. 2016 Feb;195(2):486-92.

114 Swaan A, Mannaerts CK, Scheltema MJ, Nieuwenhuijzen JA, Savci-Heijink CD, de la Rosette JJ, et al. Confocal laser endomicroscopy and optical coherence tomography for the diagnosis of prostate cancer: a needlebased, in vivo feasibility study protocol (IDEAL Phase 2A). JMIR Res Protoc. 2018 May;7(5):e132. 
115 Risi MD, Rouse AR, Chambers SK, Hatch KD, Zheng W, Gmitro AF. Pilot Clinical Evaluation of a Confocal Microlaparoscope for Ovarian Cancer Detection. Int J Gynecol Cancer. 2016 Feb;26(2):248-54

116 Chene G, Chauvy L, Buenerd A, Moret S, Nadaud B, Beaufils E, et al. In vivo confocal laser endomicroscopy during laparoscopy for gynecological surgery: A promising tool. J Gynecol Obstet Hum Reprod. 2017 Sep 46(7):565-9.

117 Wiltgen M, Bloice M. Automatic interpretation of melanocytic images in confocal laser scanning microscopy. In: Stanciu SG, edi- tor. Microscopy and analysis. InTech; 2016. https://doi.org/10.5772/63404.

118 Aubreville M, Knipfer C, Oetter N, Jaremenko C, Rodner E, Denzler J, et al. Automatic Classification of Cancerous Tissue in Laserendomicroscopy Images of the Oral Cavity using Deep Learning. Sci Rep. 2017 Sep;7(1):11979.

119 Izadyyazdanabadi M, Belykh E, Mooney MA, Eschbacher JM, Nakaji P, Yang Y, et al. Prospects for theranostics in neurosurgical imaging: empowering confocal laser endomicroscopy diagnostics via deep learning. Front Oncol. 2018 Jul;8:240.
120 Gessert N, Bengs M, Wittig L, Drömann D, Keck T, Schlaefer A, et al. Deep transfer learning methods for colon cancer classification in confocal laser microscopy images. Int J CARS. 2019 Nov; 14(11):1837-45.

121 Mooney MA, Zehri AH, Georges JF, Nakaji P. Laser scanning confocal endomicroscopy in the neurosurgical operating room: a review and discussion of future applications. Neurosurg Focus. 2014 Feb;36(2): E9.

122 Cellvizo ${ }^{\circledR}$ Lab. In vivo preclinical imaging at cellular resolution. Mauna Kea Institution; 2017. 